\title{
Identifikasi Lapisan Akuifer Dengan Metode Geolistrik Tahanan Jenis di Desa Pemangkat Kabupaten Kayong Utara
}

Ervan Alhuda', Yudha Armana ${ }^{a^{*}}$ Zulfiana

\author{
aProdi Geofisika, FMIPA Universitas Tanjungpura \\ *Email : Yudhaarman@gmail.com
}

\begin{abstract}
Abstrak
Penelitian tentang identifikasi lapisan akuifer di Desa Pemangkat Kabupaten Kayong Utara telah dilakukan dengan menggunakan metode geolistrik tahanan jenis konfigurasi Wenner-Schlumberger. Hasil dari penelitian menunjukan bahwa penyusun lapisan akuifer berupa pasir dengan nilai berkisar $1,54 \Omega \mathrm{m}$ sampai 9,7 $\Omega \mathrm{m}$. Lapisan akuifer terletak pada kedalaman 4,04 m sampai 45,6 m dengan jenis akuifer tertekan.
\end{abstract}

Kata Kunci : akuifer, geolistrik, resistivitas, Wenner-Schlumberger

\section{Latar Belakang}

Desa Pemangkat merupakan salah satu desa yang terdapat di Kabupaten Kayong Utara. Dalam memenuhi keperluan air untuk konsumsi, masyarakat Desa Pemangkat menggunakan air hujan sebagai sumber utama. Namun, dalam memenuhi kebutuhan sehari-hari akan air bersih selain konsumsi, masyarakat desa memanfaatkan air yang bersumber dari sungai, hujan, maupun sumur galian dangkal. Ancaman terhadap pencemaran air sungai serta musim kering yang berkepanjangan membuat pilihan utama untuk memenuhi kebutuhan air tersebut jatuh ke sumur galian. Kendala yang dihadapi pada pilihan ini adalah debit air sumur galian juga sangat terpengaruh kondisi cuaca. Selain itu, kualitas air yang dihasilkan juga kurang memadai mengingat tingkat kekeruhan yang dikandungnnya cukup tinggi serta warna kemerahan yang dimilikinya. Tidak adanya layanan PDAM sebagai alternatif sumber air di kondisi kering sangat menyulitkan masyarakat di desa Pemangkat dalam mendapatkan air bersih untuk keperluan sehari-hari.

Alternatif solusi bagi permasalahan ini adalah eksploitasi air bersih yang bersumber dari air formasi bawah permukaan. Air ini terdapat di lapisan akuifer, yaitu suatu lapisan yang berada di bawah permukaan yang memiliki kemampuan untuk membawa dan meloloskan air dalam jumlah yang cukup ekonomis [1].

Identifikasi serta pencarian lapisan akuifer ini dapat dilakukan dengan menggunakan berbagai metode. Salah satu metode yang umum digunakan adalah metode geolistrik tahanan jenis. Metode ini merupakan salah satu metode geofisika yang memanfaatkan tahanan jenis suatu medium hasil injeksi arus listrik di permukaan bumi, dengan penetrasi kedalaman dapat mencapai puluhan hingga ratusan meter.
Arus listrik hasil injeksi mengalir di bawah permukaan melalui material penyusun batuan dan sangat dipengaruhi oleh adanya larutan elektrolit berupa air tanah ataupun garam yang terkandung di dalamnya. Beda potensial yang muncul kemudian diukur melalui elektroda potensial di permukaan bumi. Metode ini dapat diaplikasikan untuk menentukan akuifer, kontaminasi air tanah [2], penyelidikan batubara [3], penyelidikan mineral, survei arkeologi, deteksi hostrocks pada penyelidikan panas bumi, serta estimasi kedalaman bedrock untuk pondasi bangunan [4].

\section{Metodologi}

\subsection{Tempat Penelitian}

Penelitian ini dilakukan pada kawasan pemukiman warga Dusun Pemangkat Jaya, Desa Pemangkat, Kecamatan Simpang Hilir, Kabupaten Kayong Utara, Kalimantan Barat. Secara geografis daerah penelitian terletak pada zona 49M dengan koordinat $377480,00 \mathrm{mE}$ sampai $377698,00 \mathrm{mE}$ dan dari $9880300,00 \mathrm{mN}$ sampai 9880437,00 $\mathrm{mN}$.

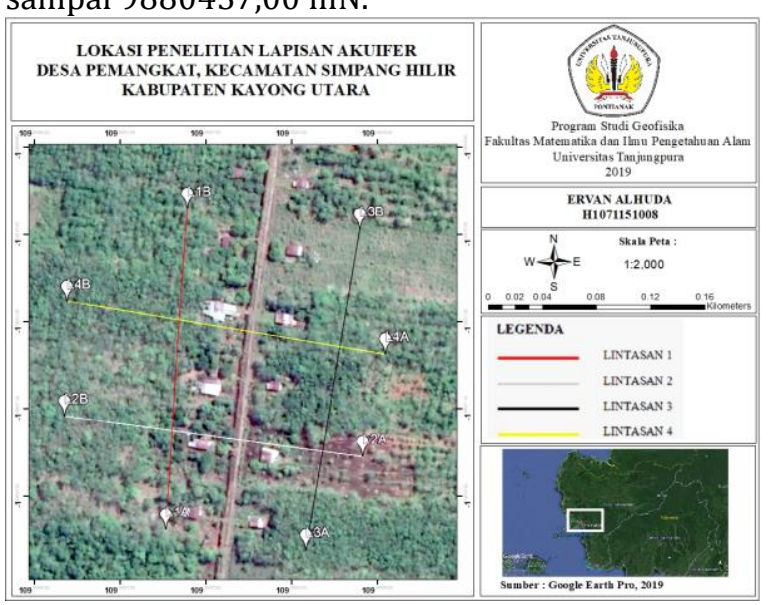

Gambar 1. Lokasi penelitian 


\subsection{Metode Geolistrik}

Metode geolistrik tahanan jenis adalah suatu metode geofisika yang memanfaatkan sifat tahanan jenis untuk mempelajari keadaan bawah permukaan bumi. Tahanan jenis merupakan parameter penting untuk mengkarakterisasikan keadaan fisis bawah permukaan yang diasosiasikan dengan material dan kondisi bawah permukaan [5].

Hambatan jenis suatu benda dapat dituliskan dengan persamaan berikut.

$$
R=\rho \frac{L}{A}
$$

Dengan, $R=$ Tahanan jenis yang terukur $(\Omega)$

$\rho=$ Tahanan jenis suatu bahan $(\Omega \mathrm{m})$

$L=$ Panjang $(\mathrm{m})$

$A=\operatorname{Luas}\left(\mathrm{m}^{2}\right)$

\subsection{Konfigurasi Wenner-Schlumberger}

Konfigurasi Wenner-Schlumberger adalah konfigurasi dengan aturan jarak spasi yang tetap dengan faktor $\mathrm{n}$ untuk konfigurasi WennerSchlumbeger dengan perbandingan jarak antara elektroda $\mathrm{C}_{1}-\mathrm{C}_{2}$ dengan spasi antara $\mathrm{P}_{1}-\mathrm{P}_{2}$. Sehingga jika jarak antar elektroda potensial $\mathrm{P}_{1}$ $\mathrm{P}_{2}$ adalah a maka jarak antar elektroda arus $\left(\mathrm{C}_{1}\right.$ dan $\mathrm{C}_{2}$ ) adalah 2na+a. Proses penentuan resistivitas menggunakan 4 buah elektroda yang diletakan dalam sebuah garis lurus (Sakka, 2002). Cakupan horizontal dan penetrasi kedalaman konfigurasi Wenner-Schlumberger lebih baik $15 \%$ dari konfigurasi Wenner [6].

Faktor geometri konfigurasi WennerSchlumberger adalah :

$$
k=\pi n(n+1) a
$$

Dengan, $k=$ Faktor geometri $(\mathrm{m})$

$$
n=\text { Jarak perbandingan } \mathrm{C}_{1} \mathrm{P}_{1} \text { dan } \mathrm{C}_{1}-\mathrm{C}_{2}
$$$$
a=\text { Jarak elektroda (m) }
$$

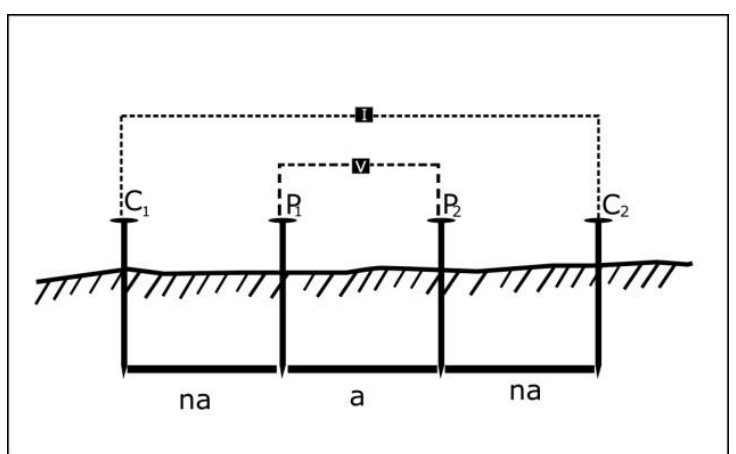

Gambar 2. Susunan elektroda konfigurasi Wenner-Schlumberger [5]

\subsection{Resistivitas Batuan}

Resistivitas adalah kemampuan suatu bahan untuk menghantarkan arus listrik yang bergantung terhadap besarnya medan listrik dan kerapatan arus. Semakin besar resistivitas suatu bahan maka semakin besar pula medan listrik yang dibutuhkan untuk menimbulkan sebuah kerapatan arus. Nilai resistivitas suatu material dimanfatkan metode geolistrik dalam upaya menyelidiki struktur bawah permukaan.

Nilai resistivitas suatu bahan dapat dituliskan dengan persamaan berikut.

$$
\rho=k \frac{\Delta V}{I}
$$

Dengan, $\Delta V=$ Beda potensial $(\mathrm{V})$

$$
I=\operatorname{Arus}(\mathrm{A})
$$

Variasi nilai resistivitas suatu material ditunjukan sebagai berikut.

Tabel 1. Variasi resistivitas material bumi

\begin{tabular}{ll}
\hline Bahan & Resistivitas $(\mathbf{\Omega m})$ \\
\hline Udara & $\sim$ \\
Pirit & $3 \times 10^{-1}$ \\
Galena & $2 \times 10^{-3}$ \\
Kwarsa & $4 \times 10^{10}$ s.d. $2 \times 10^{-14}$ \\
Kalsit & $1 \times 10^{12}$ s.d. $1 \times 10^{13}$ \\
Batuan Garam & 30 s.d $1 \times 10^{13}$ \\
Mika & $9 \times 10^{12}$ s.d. $1 \times 10^{14}$ \\
Basalt & 10 s.d. $1 \times 10^{7}$ \\
Lanau & 10 s.d. 200 \\
Batuan Gamping & 50 s.d. $1 \times 10^{7}$ \\
Batuan Pasir & 1 s.d. $1 \times 10^{8}$ \\
Batuan Serpih & 20 s.d $1 \times 10^{3}$ \\
Dolomit & $10^{2}$ s.d. $10^{4}$ \\
Pasir & 1 s.d. $10^{3}$ \\
Lempung & 1 s.d. $10^{2}$ \\
Air Tanah & 0,5 s.d $3 \times 10^{2}$ \\
Air Laut & 0,2 \\
\hline
\end{tabular}

(Sumber : Telford et al., 1998) [5]

\subsection{Pengolahan Data}

Data yang didapat adalah data resistivitas semu yang kemudian diinversikan dengan menggunakan perangkat lunak Res2Dinv sehingga didapat penampang 2D. Penampang resisitivitas 2D digunakan untuk mengidentifikasi lapisan akuifer yang terdapat pada lokasi penelitian.

\subsection{Akuisisi Data}

Penelitin ini menggunakan 4 lintasan yang masing-masing lintasan memiliki panjang $235 \mathrm{~m}$ dan spasi $5 \mathrm{~m}$. Setiap lintasan dibuat saling memotong dengan 2 lintasan lainnya. Lintasan pertama dan lintasan ketiga dibuat memotong dengan lintasan kedua dan lintasan keempat, sedangkan lintasan kedua dan lintasan keempat dibuat memotong dengan lintasan pertama dan lintasan ketiga. 


\section{Hasil dan Pembahasan}

\subsection{Hasil dan Interpretasi Lintasan 1}

Lintasan 1 membentang dari arah selatan keutara dengan arah lintasan N 3,84 ${ }^{\circ}$. Posisi elektroda pertama terletak pada koordinat UTM 49 M $377555 \mathrm{mE}$ dan $988217 \mathrm{mN}$ dengan elevasi sebesar $15 \mathrm{~m}$, sedangkan posisi elektroda terakhir terletak pada koordinat UTM 49 M $377571 \mathrm{mE}$ dan $9880452 \mathrm{mN}$ dengan elevasi sebesar $17 \mathrm{~m}$. Penampang resistivitas lintasan 1 ditunjukan oleh Gambar 3.

Lapisan batuan pertama yang memiliki nilai resistivitas paling tinggi sebesar 45,6 $\Omega \mathrm{m}$ sampai dengan $162 \Omega$ m diduga sebagai tanah gambut. Tanah gambut menjadi penyusun lapisan atas sekaligus lapisan penutup yang berada pada kedalaman 1,62 m sampai dengan 6,83 m. Lapisan batuan kedua yang memiliki nilai resistivitas $9,8 \Omega \mathrm{m}$ sampai $45,5 \Omega \mathrm{m}$ diduga sebagai lempung dan lanau. Lanau berada pada kedalaman 4,04 m sampai 12,4 m, sedangkan lempung terdapat pada dua lapisan, yaitu pada lapisan atas yang memiliki kedalaman 4,04 m sampai $12,4 \mathrm{~m}$ dan pada lapisan bawah yaitu pada kedalaman 39,7 m sampai dengan 45,6 m. Lapisan batuan ketiga yang memiliki nilai resistivitas terendah dengan nilai $1,91 \Omega \mathrm{m}$ sampai 9,7 $\Omega \mathrm{m}$ diduga sebagai pasir yang tersaturasi dengan air tanah. Lapisan ini terdapat pada kedalaman 6,83 m hingga 45,6 m yang ditunjukan oleh warna biru gelap sampai biru terang seperti ditunjukan oleh tanda panah biru pada Gambar 3.

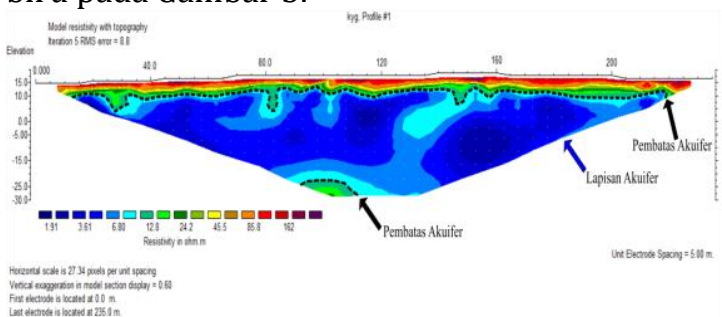

Gambar 3. Penampang resistivitas lintasan 1

\subsection{Hasil dan Interpretasi Lintasan 2}

Lintasan 2 membentang dari arah timur ke barat dengan arah lintasan $\mathrm{N} 277,31^{\circ} \mathrm{E}$. Elektroda pertama di lintasan kedua berada pada koordinat 49 M $377701 \mathrm{mE}$ dan 9880271 $\mathrm{mN}$ dengan elevasi sebesar $16 \mathrm{~m}$. Koordinat elektroda terakhir berada pada zona $49 \mathrm{M}$ $377480 \mathrm{mE}$ dan $9880300 \mathrm{mN}$ dengan elevasi sebesar $15 \mathrm{~m}$. Penampang resistivitas lintasan 2 ditunjukan oleh Gambar 4.

Lapisan batuan pertama yang memiliki nilai resistivitas paling besar diantara material lainnya dengan nilai resistivitas sebesar 39,7 $\Omega \mathrm{m}$ sampai dengan $135 \Omega \mathrm{m}$ diduga sebagai tanah gambut. Tanah gambut menjadi material penyusun lapisan atas pada lokasi penelitian sekaligus menjadi lapisan penutup yang terdapat pada kedalaman 1,25 m sampai dengan 4,04 m. Lapisan batuan kedua diduga sebagai lempung dan lanau yang memiliki nilai resistivitas sebesar 9,02 $\Omega$ m sampai dengan 39,6 $\Omega \mathrm{m}$. Lanau berada pada kedalaman 2,65 m sampai dengan kedalaman 20,14 m, sedangkan material lempung terdapat pada dua lapisan. Lapisan pertama yang terletak dekat dengan permukaan berada pada kedalaman 2,65 m sampai 9,62 $\mathrm{m}$ dan pada lapisan bawah yang berada pada kedalaman 33,8 m sampai dengan 45,6 m. Lapisan batuan ketiga yang memiliki nilai resitivitas terendah dengan nilai sebesar 1,86 $\Omega$ m sampai dengan 9,01 $\Omega$ m diduga sebagai pasir yang tersaturasi air tanah. Lapisan ini terdapat pada kedalaman mulai dari 4,04 m hingga 45,6 m yang ditunjukan oleh warna biru terang sampai biru gelap pada Gambar 4 .

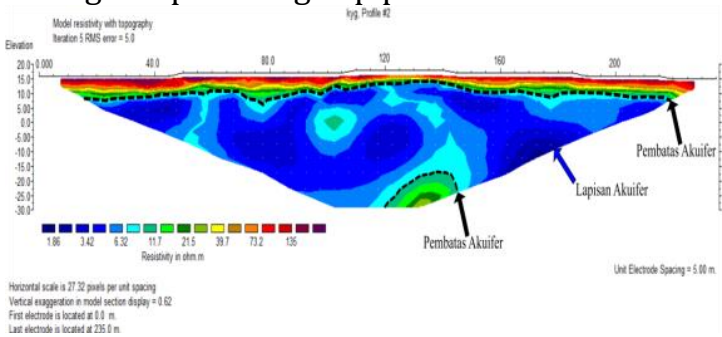

Gambar 4. Penampang resistivitas lintasan 2

\subsection{Hasil dan Interpretasi Lintasan 3}

Lintasan 3 membentang dari arah selatan kearah utara dengan arah $\mathrm{N} 9,35^{\circ}$ E. Posisi koordinat elektroda pertama pada lintasan ketiga berada dalam koordinat UTM 49 M $377659 \mathrm{mE}$ dan $9880202 \mathrm{mN}$ dengan elevasi sebesar $14 \mathrm{~m}$. Elektroda terakhir berada pada koordinat 49 M $377698 \mathrm{mE}$ dan $9880437 \mathrm{mN}$ dengan elevasi sebesar $19 \mathrm{~m}$. Penampang resistivitas lintasan 3 ditunjukan oleh Gambar 5.

Lapisan batuan pertama yang memiliki nilai resistivitas terbesar diantara material lain pada lintasan ketiga dengan nilai sebesar 33,7 $\Omega \mathrm{m}$ sampai $115 \Omega \mathrm{m}$. Lapisan ini diduga sebagai tanah gambut yang menjadi penyusun lapisan atas sekaligus menjadi lapisan penutup pada lokasi penelitian. Lapisan batuan kedua diduga sebagai lempung dan lanau yang memiliki nilai resistivitas sebesar 7,55 $\Omega$ m sampai dengan 33,6 $\Omega \mathrm{m}$. Lapisan yang mengandung lanau berada pada kedalaman 4,04 m sampai 6,83 m. Lapisan lempung terdapat pada dua lapisan, pada lapisan atas lempung yang brcampur dngan lanau terdapat pada kedalaman 4,04 m sampai dengan 9,62 m, sedangkan pada lapisan bawah lempung terdapat pada kedalaman $41 \mathrm{~m}$ sampai 45,6 m. Lapisan batuan ketiga yang memiliki nilai resistivitas terendah sebesar $1,54 \Omega \mathrm{m}$ 
sampai dengan $7,54 \Omega \mathrm{m}$ yang ditunjukan oleh warna biru gelap hingga biru terang pada Gambar 5. Pelapisan batuan ini diduga sebagai pasir yang tersaturasi dengan air tanah. Lapisan ini terdapat pada kedalaman 6,83 m hingga 45,6 $\mathrm{m}$.

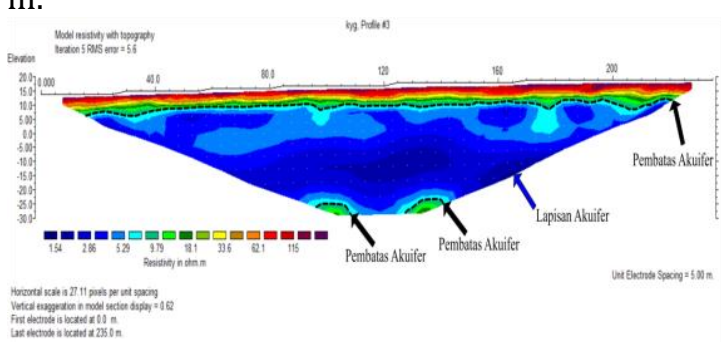

Gambar 5. Penampang resistivitas lintasan 3

\subsection{Hasil dan Interpretasi Lintasan 4}

Lintasan 4 membentang dari arah timur kearah barat dengan arah lintasan $\mathrm{N} 279,4^{\circ} \mathrm{E}$. Koordinat elektroda pertama dari lintasan keempat adalah $377717 \mathrm{mE}$ dan $9880346 \mathrm{mN}$ yang berada pada zona $49 \mathrm{M}$ dengan elevasi sebesar $18 \mathrm{~m}$. Koordinat elektroda terakhir lintasan keempat adalah $377482 \mathrm{mE}$ dan $9880384 \mathrm{mN}$ yang berada pada zona $49 \mathrm{M}$ dengan elevasi sebesar $16 \mathrm{~m}$. Penampang resistivitas lintasan 4 ditunjukan oleh Gambar 6.

Lapisan batuan pertama memiliki nilai resistivitas terbesar diantara lapisan lainnya yaitu sebesar $38,1 \Omega \mathrm{m}$ sampai dengan $137,0 \Omega \mathrm{m}$. Lapisan ini diduga sebagai tanah gambut yang terdapat pada kedalaman 1,25 m sampai 9,62 m. Tanah gambut merupakan lapisan penutup pada lokasi penlitian. Lapisan batuan kedua memiliki nilai resistivitas sebesar 8,04 $\Omega \mathrm{m}$ sampai 38,0 $\Omega \mathrm{m}$ diduga sebagai lempung dan lanau. Lapisan lanau berada pada kedalaman 4,01 m sampai dengan 6,83 $\mathrm{m}$ yang berada dekat dengan permukaan. Lapisan lempung terdapat pada dua lapisan, pada lapisan atas material lempung yang bercampur dengan lanau terdapat pada kedalaman 4,01 m sampai dengan 9,62 m sedangkan pada lapisan bawah lempung berada pada kedalaman 39,7 m sampai 45,6 m. Lapisan batuan ketiga yang memiliki nilai resistivitas terendah diduga sebagai pasir yang tersaturasi air tanah dengan nilai rsistivitas yang didapat sebesar 1,54 $\Omega \mathrm{m}$ hingga 8,03 $\Omega \mathrm{m}$. Lapisan ini digambarkan dengan warna biru gelap hingga biru terang pada Gambar 6. Lapisan ini terdapat pada kedalaman 4,04 $\mathrm{m}$ hingga 45,6 $\mathrm{m}$.

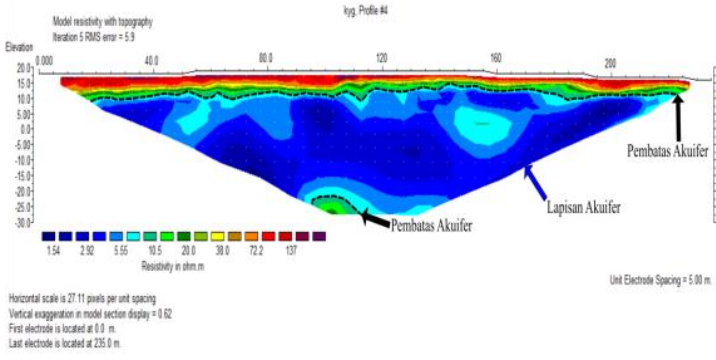

Gambar 6. Penampang resistivitas lintasan 4

\subsection{Hasil dan Interpretasi 3D}

Hasil visualisasi 3 dimensi digunakan untuk mengetahui sebaran dan penerusan lapisan akuifer. Sebaran lapisan akuifer dapat dilihat pada Gambar 7.

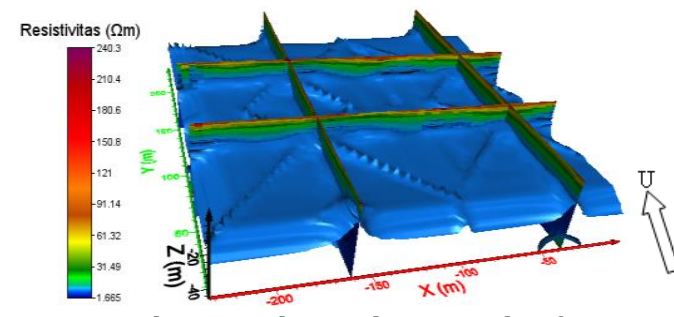

Gambar 7. Sebaran lapisan akuifer

Berdasarkan Gambar 7 dapat diketahui bahwa lapisan akuifer yang tersusun oleh material pasir tersebar diseluruh lokasi penelitian. Hal ini mengindikasikan bahwa lapisan akuifer terdapat diseluruh lokasi penelitian dengan kedalaman yang bervariasi. Tempat terakumulasinya air tanah diperkirakan berada di sebelah tenggara yaitu diantara titik potong lintasan 2 dan lintasan 3.

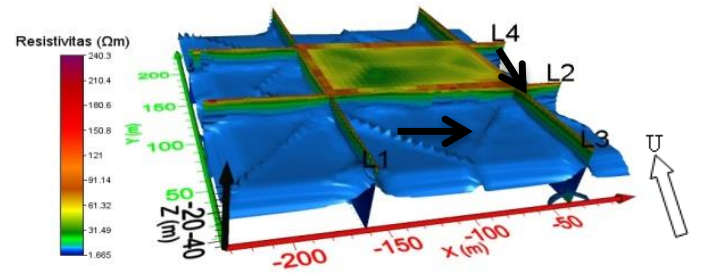

(a)

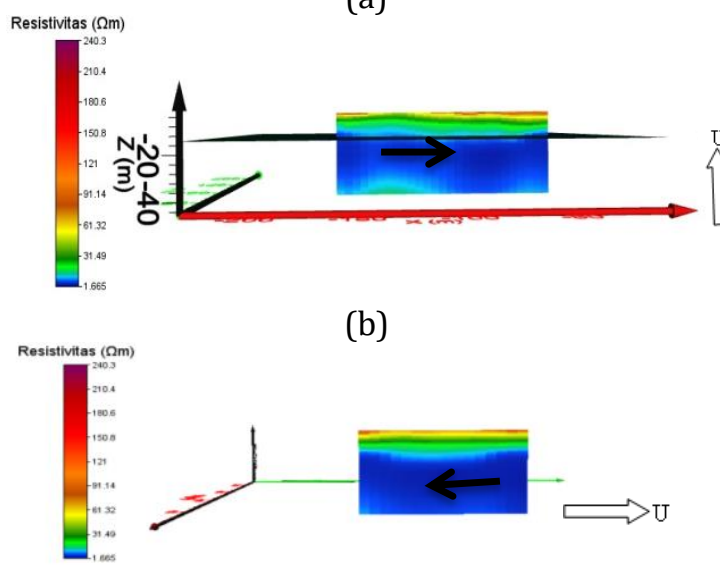

(c)

Gambar 8. Penerusan akuifer (a) tampak atas. (b) tampak dari utara ke selatan, (c) tampak dari timur ke barat 
Sedangkan untuk penerusan akuifer lebih cenderung kearah tenggara, hal ini dapat dilihat dari tingkat kedalaman akuifer terhadap permukaan tanah dan elevasi lokasi penelitian yang memperlihatkan bahwa semakin kearah tenggara maka elevasinya juga akan semakin rendah. Hal ini sesuai dengan sifat fluida yang mengalir dari tempat tinggi ketempat yang lebih rendah. Penerusan akuifer dapat dilihat pada Gambar 8.

\section{Kesimpulan}

Berdasarkan hasil penelitian dapat disimpulkan bahwa lapisan akuifer terdapat diseluruh lokasi penelitian dengan kedalaman mulai dari 4,04 m sampai 45,6 m yang memiliki material penyusun berupa pasir dengan arah penerusan lebih cenderung kearah tenggara.

\section{Daftar Pustaka}

[1] Ray, L. K., Kohler, M. A. and J, L. H., Hidrologi untuk insinyur, 3th ed., Erlangga, 1989.

[2] Irawati., Abd, R. and Dahlan, T. M., Identifikasi Sebaran Aquifer Menggunakan Metode Geolistrik Hambatan Jenis Di Desa Bora Kecamatan Sigi Biromari Kabupaten Sigi, Jurnal of Natural Scince, 223-233, 2016.

[3] Azhar. and Gunawan, H., Penerapan Metode Geolistrik Konfigurasi Schlumbeger untuk Penentuan Tahanan Jenis Batubara., Jurusan Geofisika Terapan ITB, 2004. [Bandung].

[4] Hendrajaya, L. and Arif, I., Geolistrik Tahanan Jenis., Laboratorium Fisik Bumi Jurusak Fisika ITB, 1990. [Bandung]

[5] Telford, W. M., Geldart, L. P., Sheriff, R. E. and Keys, D. A., Appleied geophysics, 1st ed., Cambrigdge University Press, 1998. [Cambrigdge].

[6] Loke, M., Electrical Imaging Surveys for Environmental and Engineering Studies: A Partical Guide to 2-D and 3-D Surveys, 2000. 